九州大学学術情報リポジトリ

Kyushu University Institutional Repository

\title{
Descriptions of Male and Female Genitalia of Kricognia lyside (Lepidoptera: Pieridae: Coliadinae)
}

\section{Yamauchi, Takeo}

Setouchi Field Science Center, Graduate School of Biosphere Science, Hiroshima Uniersity

Yata, 0samu

Biosystematics Laboratory, Faculty of Social and Cultural Studies, Kyushu University

https://doi.org/10.5109/2697

出版情報: ESAKIA. 44，pp.217-224，2004-03-31. Entomological Laboratory，Faculty of Agriculture, Kyushu University バージョン：

権利関係 : 
ESAKIA, (44): 217-224. March 10, 2004

Descriptions of Male and Female Genitalia of $\mathbb{K r i c o g o n i a}$ lyside (Lepidoptera: Pieridae: Coliadimae)

\author{
Takeo YAMAUCHI \\ Setouchi Field Science Center, Graduate School of Biosphere Science, \\ Hiroshima University, Higashi-Hiroshima, 739-8528 Japan \\ and \\ Osamu YATA \\ Biosystematics Laboratory, Faculty of Social and Cultural Studies, \\ Kyushu University, Fukuoka, 810-8560 Japan
}

\begin{abstract}
The male and female genitalia of Kricogonia lyside (Godart, 1819), the type species of the genus Kricogonia Reakirt, 1863, are described and figured in detail, which is for the first time for female. The unique character states of female genitalia newly found in the family Pieridae are discussed.

Key words: Kricogonia lyside, Coliadinae, Pieridae, male genitalia, female genitalia, description.
\end{abstract}

\title{
Introduction
}

The genus Kricogonia Reakirt, 1863 belonging to the subfamily Coliadinae (Lepidoptera: Pieridae) is distributed from the southern United States to Venezuela, Cuba and the Antilles (Smith et al., 1994). According to Smith et al. (1994), two species are recognized from these areas: Kricogonia lyside (Godart, 1819), the type species of Kricogonia, and Kricogonia cabrerai Ramsden, 1920.

Klots (1933) published an excellent generic revision of the family Pieridae in which he illustrated and described the male genitalia of $K$. lyside, but the relationship of Kricogonia to other pierid genera was not clearly shown. Afterward, Luis (1958) described and figured the male genitalia of Kricogonia castalia lyside (Latreille, 1819) and K. cabrerai, while the 
female genitalia have not been studied so far.

In the present paper, we illustrate and describe the male and female genitalia of $K$. lyside based on the Mexican materials, especially the female genitalia of the species illustrated herein for the first time. Moreover, we discuss unique features found in the female genitalia.

\section{Materialls and Methods}

The specimens used in this study are kept in the collection of Biosystematics Laboratory, Faculty of Social and Cultural Studies, Kyushu University.

The methods used for dissection and drawings followed Yamauchi \& Yata (2000).

The terminology mostly followed Kusnezov (1915) and Shirôzu (1960). The term 'ductus bursae' is used to refer to the more or less slender portion of the bursa copulatrix.

\section{Kricogonia lyside (Godart, 1819)}

(Figs. 1-6)

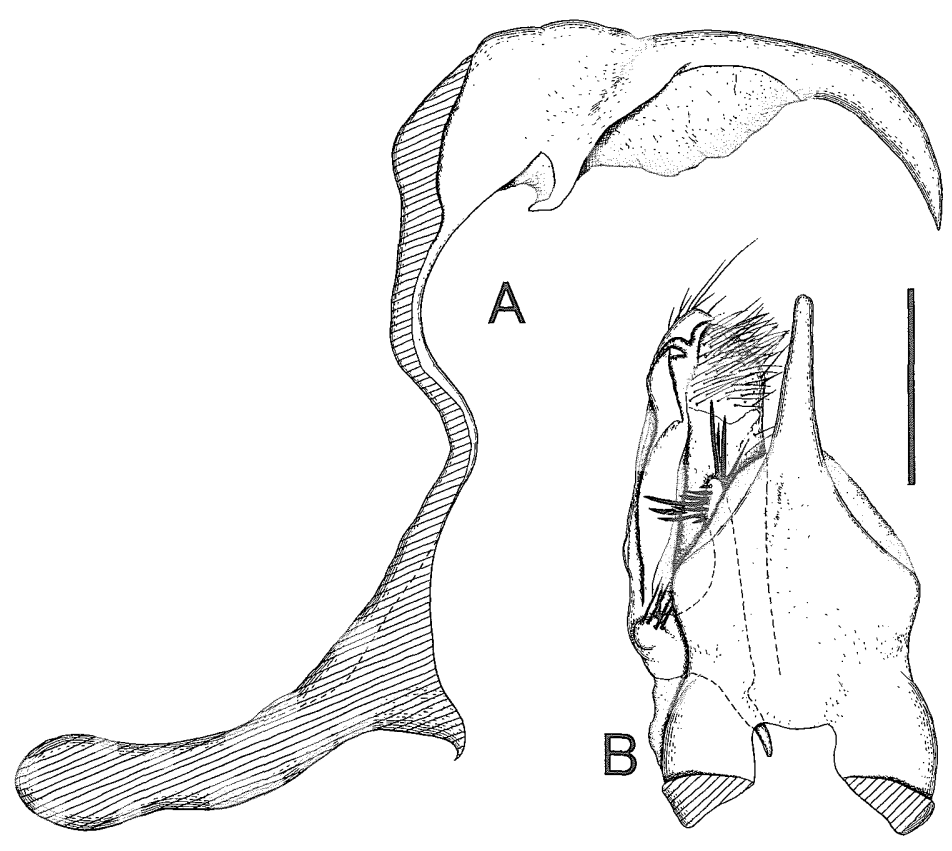

Fig. 1. Male genitalia of Kricogonia lyside (TY-Kri8). A: Ring (lateral). B: Dorsum and valva (dorsal). Scale $=1.0 \mathrm{~mm}$. 


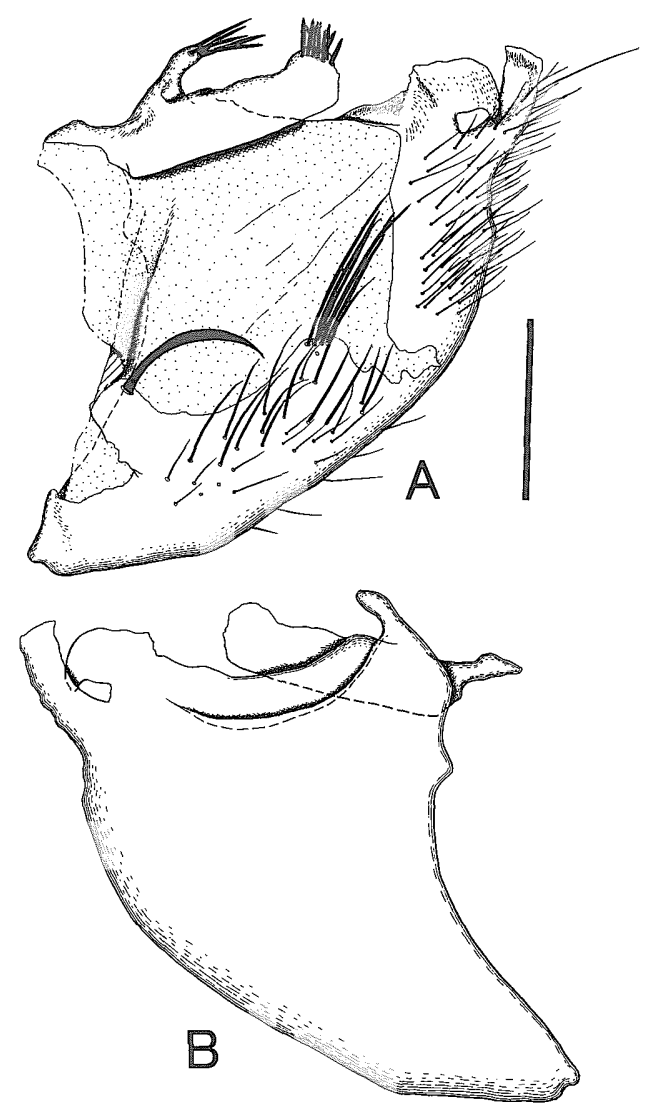

Fig. 2. Male genitalia of Kricogonia lyside (TY-Kri5). A: Valva (inner aspect of rightside). B: Valva (outer aspect of right-side). Scale $=1.0 \mathrm{~mm}$.

Male genitalia (Figs. 1-3): Posterior portion of 8th abdominal tergum somewhat straight. Tegumen trapezoidal, smooth, well sclerotized; Valvenansatz small, protruding anteroventrally; vinculum very narrow; its middle portion arched posteriorly in lateral view; saccus moderately long (about 0.6 of ring height) and stout. Uncus long (dorsum proper about same as long as height of ring), simple; proximal area depressed shallowly. Valva almost as long as high; costa protruding posteriorly; costal inner wall with long flat process protruding posteriorly, bearing a patch of stout setae (15-20) at end; costal dorsal margin with small process protruding posterodorsally, bearing stout setae (about 5) at end; ampulla angulated as free process; distal process spatulate; harpe + ampulla area bearing setae; sacculus bearing setae sparsely; a patch of stout setae (4-5) long, bearing at dorsal 
end of sacculus; a patch of stout setae (1-2) long, curved dorsally, bearing at proximal portion of sacculus; outer wall of valva with transverse groove running in parallel with dorsal margin of valva, from small dorsal process to distal region of valva. Juxta broad, kite-shaped. Phallus very long and slender, arching dorsally; subzonal sheath about 1/7 of length of phallus; bulbus ejaculatorius arising from anterodorsal end of phallus.

Female genitalia (Figs. 4-6): Hind margin of 7th abdominal sternum protruding posteriorly, with sclerotized inner pouch at lateroproximal end of protruding area; its spatulate inner edge protruding posterodorsally. Lamella antevaginalis membranous; lamella postvaginalis with pair of shallow concavities; apophysis anterioris needle-shaped, with elliptical lobulus vaginalis proximally. Ventral region of intersegmental membrane between 7th and 8th abdominal segments produced large membranous sac. Ostium bursae covered with protruding hind margin of 7 th abdominal sternum; ductus bursae membranous; its posterior half flattened, swollen in lateral view; its anterior half slender, plicate, drain-shaped; ductus seminalis slender ventrally and stout dorsally, attach at anteri-

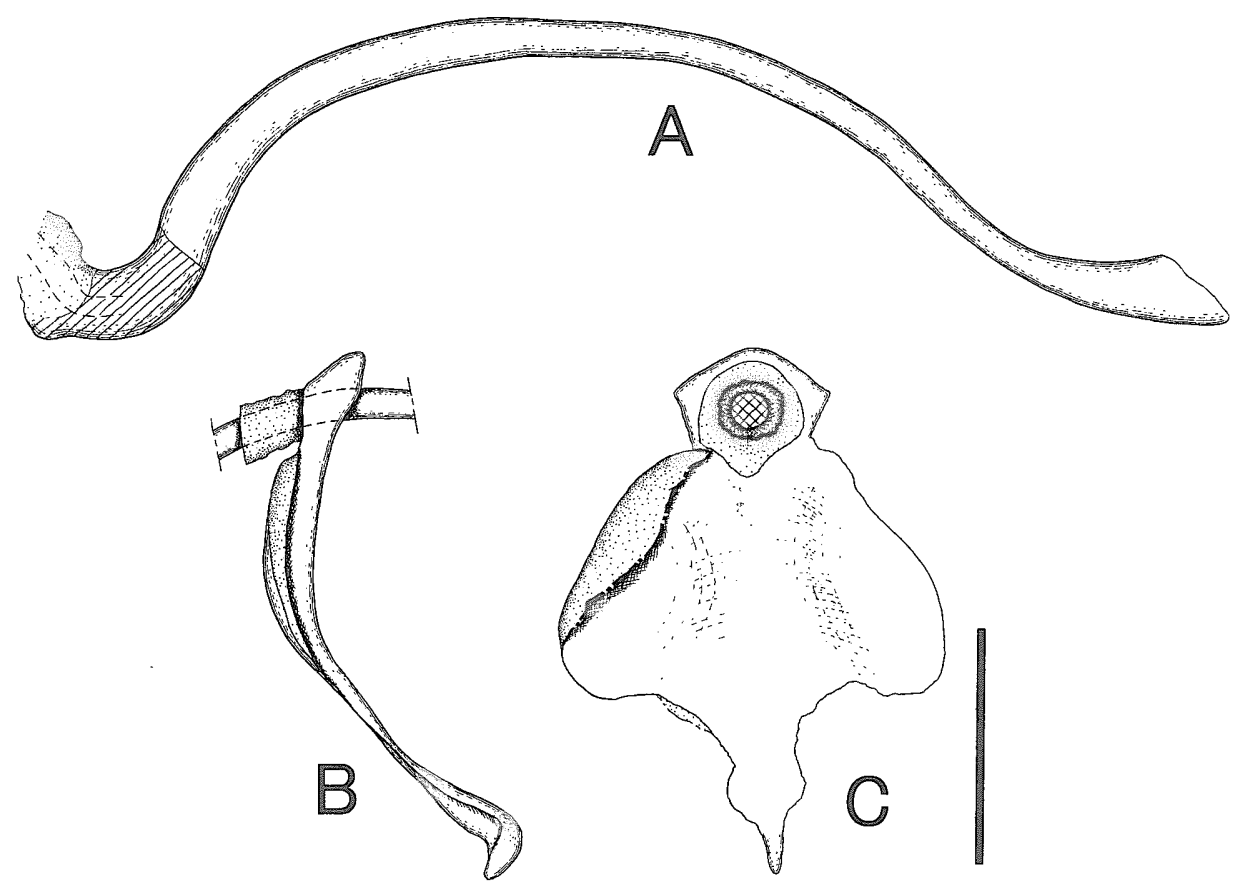

Fig. 3. Male genitalia of Kricogonia lyside (TY-Kri5). A: Phallus (lateral). B: Juxta (lateral). C: Juxta (posterior). Scale $=1.0 \mathrm{~mm}$. 


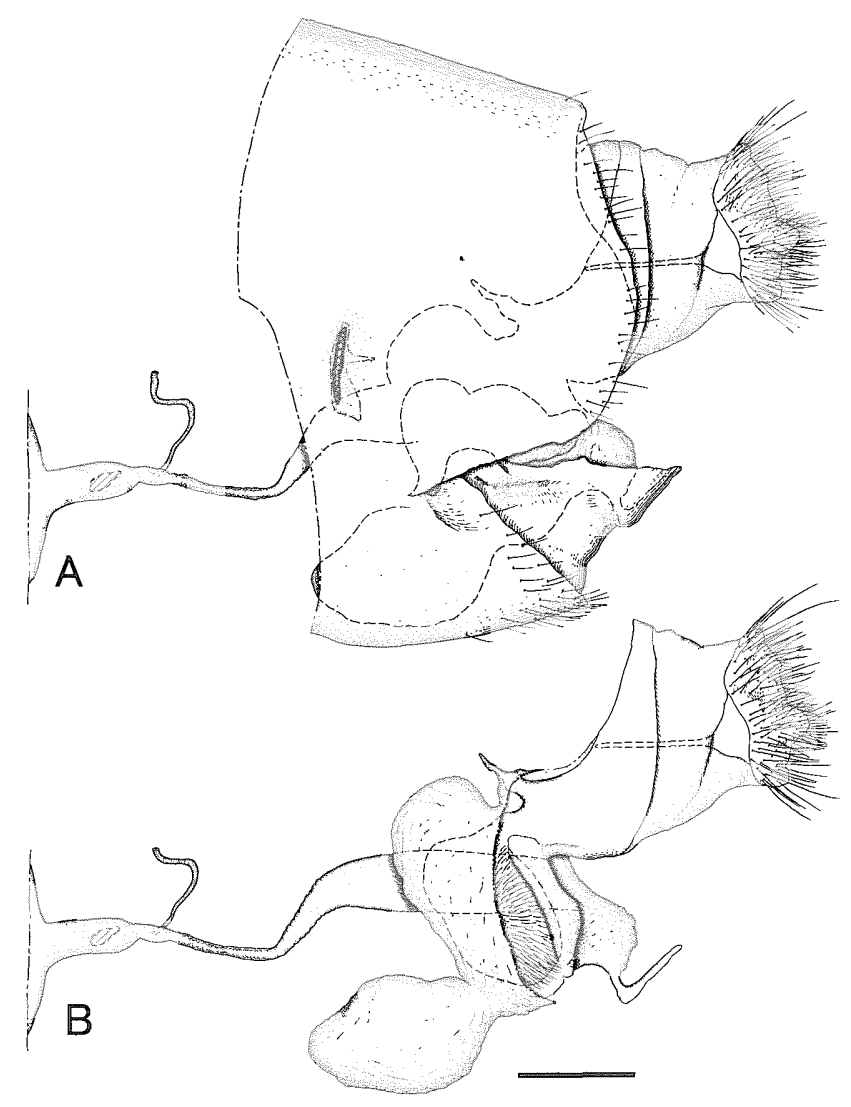

Fig. 4. Female genitalia of Kricogonia lyside (TY-Kri5). A: lateral. B: lateral (7th segment removed). Scale $=1.0 \mathrm{~mm}$.

or of ductus bursae; posterior signum well sclerotized, with no spines, small, lamellate, situated near opening of ductus bursae right-side; anterior signum well sclerotized, transversely elongate, symmetrical, with many weak spines, situated on dorsal midcorpus. Glandula receptaculi branched near basal portion. Papilla analis elongated dorsally, with prominent apical lobe; anteromedian bare-region markedly swollen; apophysis posterioris long and slender.

Genitalia examined: [MEXICO]: 1 male, X-Can, Quintata Roo, 7 May 1968 (TY-Kri4); 1 male, X-Can, Quintata Roo, 5 June 1968 (TY-Kri8); 1 male, Piste Yucatan, 8 July 1968 (TY-Kri2); 1 male, Piste Mpio. Tinum Yucatan, 16 August 1975 (TY-Kri1); 1 male, X-Can Nuevo, Quintata Roo, 25 August 1975 (TY-Kri7); 1 male, Piste Yucatan, 14 July 1968 (OY- 
401); 1 male, Piste Yucatan, 30 July 1968 (OY-402); 1 female, Mr. Hirayama (OY-381, the Property of Ent. Lab. Kyushu University); 1 female, Piste Yucatan, 14 July 1968 (TY-Kri3); 1 female, X-Can Nuevo, Quintata Roo, 21 August 1975 (TY-Kri6); 1 female (TY-Kri5).

\section{Discussion}

After close examination of genitalia of $K$. lyside, we confirmed the modified male genitalia as figured by Klots (1933) and Luis (1958), and recognized unique conditions of the female genitalia for the family Pieridae as follows: (i) posteriorly protruding 7th abdominal sternum with two steps (ii) elliptical lobuli vaginalis, (iii) large membranous sac producing from ventral region of intersegmental membrane between 7 th and 8 th abdominal segments, (iv) two signa (anterior and posterior). Moreover, we found unique conditions in the subfamily Coliadinae as follows: (v) membranous and flattened ductus bursae. Hence, the female genitalia of $K$. lyside is fairly different from those of the subfamily Coliadinae:

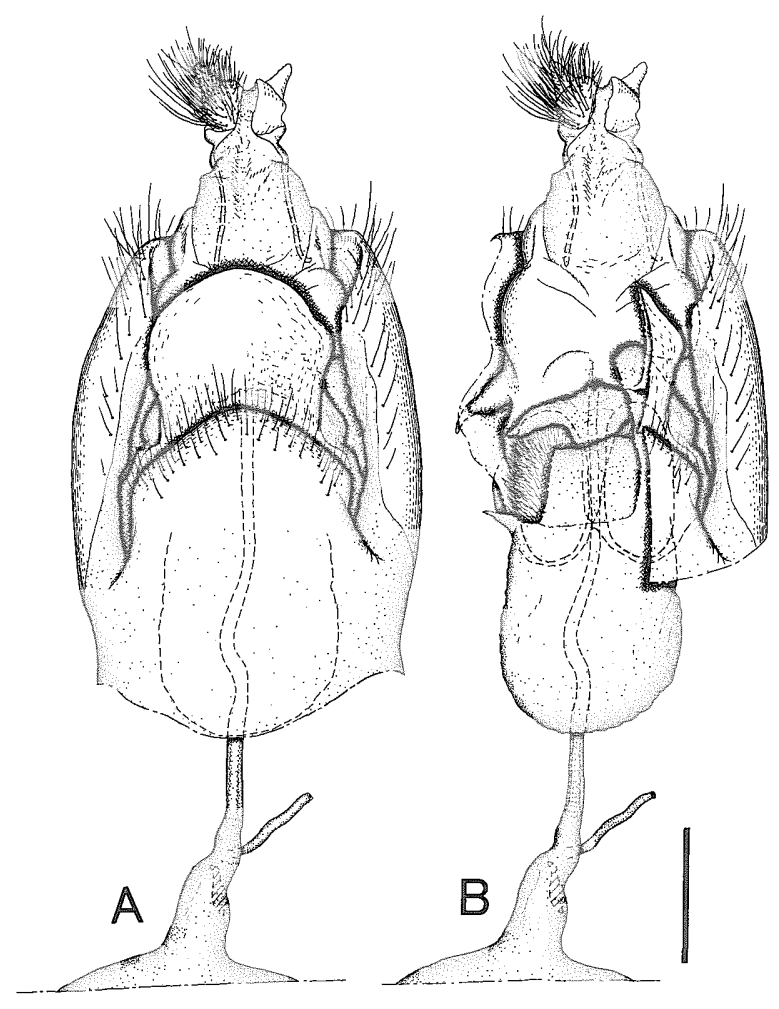

Fig. 5. Female genitalia of Kricogonia lyside (TY-Kri5). A: ventral. B: ventral (left half of 7 th segment removed). Scale $=1.0 \mathrm{~mm}$. 


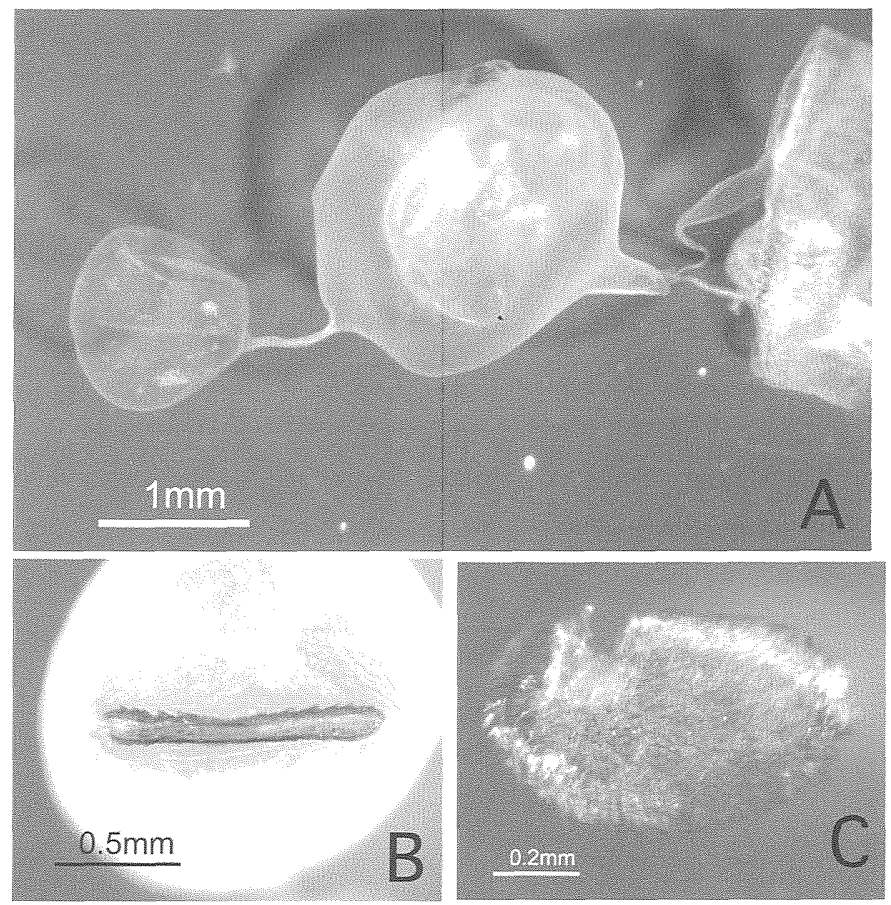

Fig. 6. Female genitalia of Kricogonia lyside (A: TY-Kri6; B, C: TY-Kri3). A: bursa copulatrix (lateral). B: anterior signum (dorsal). C: left lobulus vaginalis (lateral).

Catopsilia (Van Son, 1949), Colias (Miller, 1987; Pierce \& Beirne, 1975), Eurema (Casagrande \& Mielke, 1979; Field, 1950; Van Son, 1949; Yata, 1981, 1989), Gandaca (Yamauchi \& Yata, 2000), Gonepteryx (Pierce \& Beirne, 1975), Phoebis (Coutsis, 1986; Scott, 1986).

The anterior signum situated on the dorsal midcorpus has many weak spines and it may serve for destruction of spermatophores after copulation. On the other hand, having no spines, the posterior signum situated near the opening of ductus bursae may not be instrumental in it.

To our knowledge, the lobuli vaginalis are lamellar and divided into some lobes in the subfamily Pierinae. In $K$. lyside, they are elliptical and not divided, and so fairly different from one of Pierinae (e.g. Miller, 1987; Van Son, 1949; Yata, 1981).

During copulation, a pair of sclerotized inner pouch in the 7 th abdominal sternum is presumably hooked by the ampullae of valvae. The curvature of phallus corresponds to the one of ductus bursae.

Judging from its unique morphology of genitalia, Kricogonia is considered to be a rather isolated genus in the family Pieridae. 


\section{Acknowledgments}

We sincerely thank Prof. Junichi Yukawa for his continuous encouragement, and dedicate this paper to him in commemorating his retirement from Kyushu University.

\section{References}

Casagrande, M. M. \& O. H. H. Mielke, 1979. Eurema (Eurema) furtadoi sp. n. de Mato Grosso, Brasil (Lepidoptera, Pieridae). Dusenia, 11(3): 137-142.

Coutsis, J. G., 1986. Male and female genitalia of Phoebis editha (Butler): How they differ from Hispaniolan P. sennae (Linnaeus) (Pieridae). J. Lepid. Soc., 40: 97-106.

Field, W. D., 1950. A revision of <Eurema $>$ Hübner subgenus <Teriocolias $>$ Rober (Lepidoptera: Pieridae). Acta Zool. Lilloana, 9: 359-373, 3 pls.

Klots, A. B., 1933. A generic revision of the Pieridae (Lepidoptera) together with a study of the male genitalia. Entomol. Amer., 12: 139-242, 9 pls.

Kusnezov N. J., 1915. Insectes Lepidopteres (Insecta Lepidoptera). Volume 1. Introduction. Faune de Russie et des pays Limitrophes. 336 pp. Petrograd. (In Russian.)

Luis, S., 1958. Reconsideracion taxonomica de las especies del genero Kricogonia Reakirt, con vista al estudio de sus organos genitales. Univ. Oriente Dep. Ext. Relac. Cult., 42: $1-32$.

Pierce, F. N. \& B. P. Beirne, 1975 (1938). The Genitalia of the British Rhopalocera and the Larger Moths. xiv +66 pp., 21 pls., E. W. Classey Ltd. Faringdon, Oxon.

Scott, J. A. 1986. The Butterflies of North America; A Natural History and Field Guide. [xvi] +583 pp., 64 pls. Stanford University Press, California.

Shirôzu, T. 1960 . Butterflies of Formosa in Color. 481 pp. Hoikusha, Osaka. (In Japanese.)

Smith, D. S., L. D. Miller \& J. Y. Miller, 1994. The Butterflies of the West Indies and South Florida. 264 pp. , Oxford Univ. Press. Oxford.

Yamauchi, T. \& O. Yata, 2000. Systematics and biogeography of the genus Gandaca Moore (Lepidoptera: Pieridae). Entomol. Sci., 3: 331-343.

Yata, O., 1981. Pieridae. pp. 205-438, pls. 1-84, In Tsukada, E. (ed.), Butterflies of the South East Asian Islands, 2 (Japanese edn.). Plapac Co., Ltd., Tokyo.

Yata, O. 1989. A revision of the Old World species of the genus Eurema Hübner (Lepidoptera, Pieridae). Part I. Phylogeny and biogeography of the subgenus Terias and description of the subgenus Eurema. Bull. Kitakyushu Mus. Nat. Hist., (9): 1-103, pls. $1-24$. 